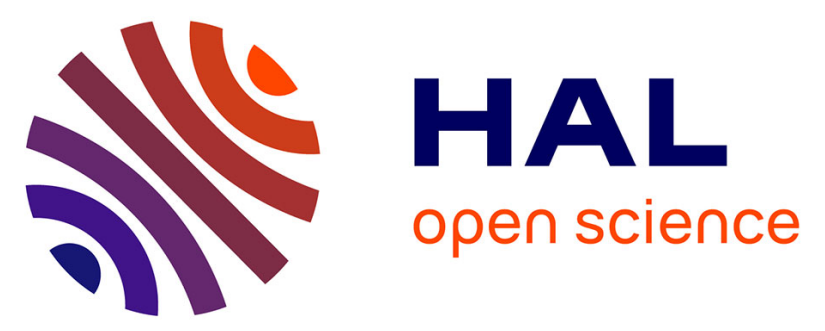

\title{
Dihydroquinoline Carbamate DQS1-02 as a Prodrug of a Potent Acetylcholinesterase Inhibitor for Alzheimer's Disease Therapy: Multigram-Scale Synthesis, Mechanism Investigations, in Vitro Safety Pharmacology, and Preliminary in Vivo Toxicology Profile
}

Florent Alix, Vincent Gembus, Laurent Coquet, Marie Hubert-Roux, Philippe Chan, Lina Truong, Muriel Sebban, Gaël Coadou, Hassan Oulyadi, Cyril Papamicaël, et al.

\section{To cite this version:}

Florent Alix, Vincent Gembus, Laurent Coquet, Marie Hubert-Roux, Philippe Chan, et al.. Dihydroquinoline Carbamate DQS1-02 as a Prodrug of a Potent Acetylcholinesterase Inhibitor for Alzheimer's Disease Therapy: Multigram-Scale Synthesis, Mechanism Investigations, in Vitro Safety Pharmacology, and Preliminary in Vivo Toxicology Profile. ACS Omega, 2018, 3 (12), pp.18387-18397. 10.1021/acsomega.8b02121. hal-03134333

\section{HAL Id: hal-03134333 \\ https://hal.science/hal-03134333}

Submitted on 8 Feb 2021

HAL is a multi-disciplinary open access archive for the deposit and dissemination of scientific research documents, whether they are published or not. The documents may come from teaching and research institutions in France or abroad, or from public or private research centers.
L'archive ouverte pluridisciplinaire HAL, est destinée au dépôt et à la diffusion de documents scientifiques de niveau recherche, publiés ou non, émanant des établissements d'enseignement et de recherche français ou étrangers, des laboratoires publics ou privés. 


\section{Dihydroquinoline Carbamate DQS1-02 as a Prodrug of a Potent Acetylcholinesterase Inhibitor for Alzheimer's Disease Therapy: Multigram-Scale Synthesis, Mechanism Investigations, in Vitro Safety Pharmacology, and Preliminary in Vivo Toxicology Profile}

Florent Alix, ${ }^{\dagger}$ Vincent Gembus, ${ }^{*}{ }^{\dagger}$ (๑) Laurent Coquet, ${ }^{\ddagger}$ Marie Hubert-Roux, ${ }^{\S}$ Philippe Chan, Lina Truong, ${ }^{\S}$ Muriel Sebban, ${ }^{\S}$ Gaël Coadou, ${ }^{\S}$ Hassan Oulyadi, ${ }^{\S}$ Cyril Papamicaël, ${ }^{\S}$ and Vincent Levacher*, ${ }^{*}(0)$

${ }^{\dagger}$ VFP Therapies, R\&D, 1 Rue Tesnière, 76130 Mont Saint Aignan, France

${ }^{\ddagger}$ CNRS UMR6270, Normandie Université, UNIROUEN, Plateforme PISSARO, IRIB, Tremplin I2C, 76821 Rouen, France

${ }^{\S}$ Normandie Université, UNIROUEN, INSA Rouen, CNRS, COBRA, 76000 Rouen, France

Supporting Information
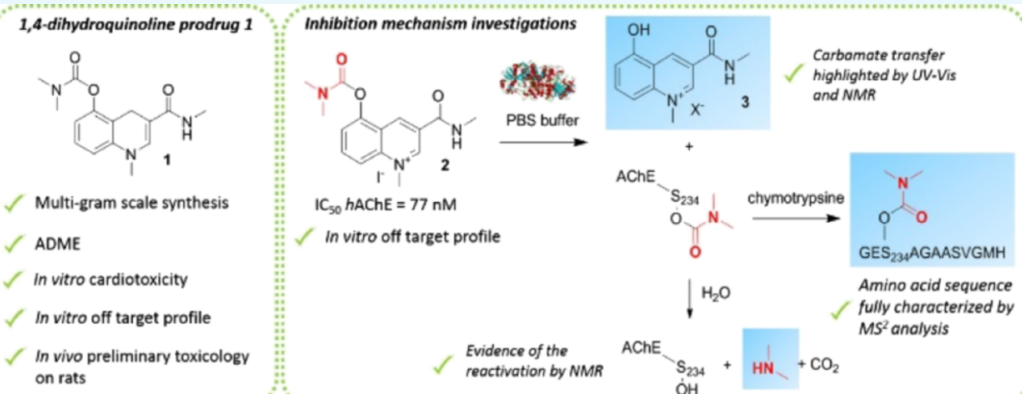

ABSTRACT: We previously characterized a set of potent pseudo-irreversible inhibitors of acetylcholinesterase (AChE) based on a redox prodrug strategy. Among the various synthesized prodrugs, compound 1, namely DQS1-02, displayed favorable physicochemical properties and was chosen to achieve the necessary prerequisite investigations prior to preclinical evaluation. Herein, we first report a practical multigram-scale nine-step synthesis of prodrug 1 with a good overall yield (18\%) as well as a full investigation on the inhibition mechanism of AChE by the parent drug 2 by means of UV-vis spectroscopy, NMR, and tandem mass spectrometry. In the second part, we describe the ADME properties of DQS1-02, the safety pharmacology of both compounds 1 and 2, and the preliminary results of an in vivo toxicology study in rats. Last but not the least, we also demonstrated that $\mathrm{AChE}$ inhibitor 2 was highly selective for AChE, whereas the corresponding prodrug 1 proved to be remarkably safe, making it a valuable preclinical candidate.

\section{INTRODUCTION}

During the last decade, considerable efforts of many laboratories and pharmaceutical companies were made to develop disease-modifying therapies for Alzheimer's disease $(\mathrm{AD})$ to stop or drastically slow down its progression. ${ }^{1-6}$ Indeed, many drugs such as secretase inhibitors or modulators, ${ }^{7-10}$ mono- or polyclonal antibodies, ${ }^{11,12}$ microtubule stabilizers or tau aggregation inhibitors, ${ }^{13-16}$ and others $^{3,17-21}$ targeting mainly $\beta$-amyloid or tau protein have been studied and some of them proved to be efficient in small animal models during preclinical studies. However, irrespective of the targets or the investigated drugs, most of the candidates failed in clinical trials because of severe adverse effects or lack of efficacy. $2,4,14,22-24$ Although the discovery of curative treatments continues to be a major goal to achieve, but elusive in the short term, the search of new drugs for the symptomatic treatment of $\mathrm{AD}$ with a lower side-effect profile compared to approved products such as donepezil or rivastigmine is still relevant. $^{25-29}$ In this context, we were interested in search of such new drugs to improve the therapeutic efficacy and tolerability of current symptomatic treatments of $\mathrm{AD}$. We previously reported the rational design of prodrugs of acetylcholinesterase (AChE) inhibitors based on the redox activation approach. ${ }^{30}$ Miscellaneous couples of bioprecursor/ active forms were synthesized and showed to be able to specifically inhibit brain AChE. The proof of concept for brain delivery of the active form of these prodrugs was demonstrated in vivo after intraperitoneal injection in mice and monitoring markers of central and peripheral cholinergic activation compared to tacrine (Cognex) as ref 31 . To support these

Received: August 21, 2018

Accepted: November 14, 2018

Published: December 27, 2018 
results, a radiosynthesis of ${ }^{11} \mathrm{C}$-radiolabeled prodrug was also developed for additional ex vivo studies in rats, and radio-highperformance liquid chromatography (HPLC) analyses of brain samples confirmed the rapid central nervous system (CNS) penetration of $\left[{ }^{11} \mathrm{C}\right]$-prodrug, while identification of the corresponding parent $\left[{ }^{11} \mathrm{C}\right]$-drug accounts for central redox activation of the prodrug to its active form. In line with the development of these innovative class of prodrugs, we next envisioned to gain insight into the mechanism of action of the ligand 2 (Figure 1). Although compound 1 was specifically

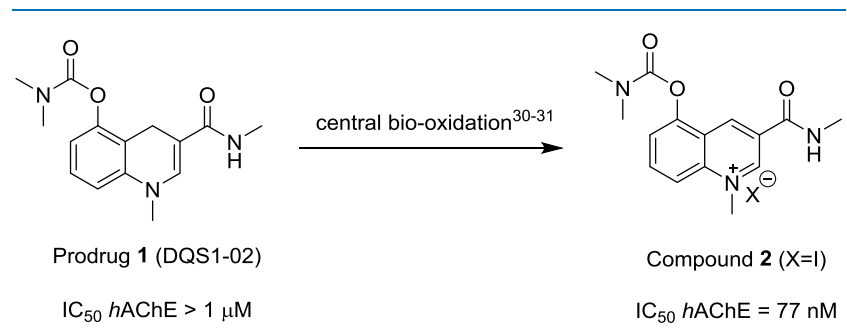

Figure 1. Structure of prodrug $\mathbf{1}$ and its active compound 2.

designed as a prodrug of an analog of rivastigmine and thus putatively acts as a pseudo-irreversible carbamate AChE inhibitor, it was essential to demonstrate its mode of action for the future clinical development of DQS1-02.

Indeed, evidence on the mechanism of action and on the biochemical process is crucial to anticipate further important parameters such as dosing, kinetic, establishment of biomarkers strategies, or the side-effect profile linked to off-targets.

In this report, we describe the following: (a) the multigramscale synthesis of prodrug 1 ; (b) a comprehensive study on the mechanism of inhibition of AChE by ligand 2 using UV spectroscopy, NMR, and tandem mass spectrometry; (c) the ADME and in vitro pharmacology profile of both compounds 1 and 2; and (d) the preliminary in vivo toxicology on rats.

\section{RESULTS AND DISCUSSION}

Multigram-Scale Synthesis. Our initial synthesis ${ }^{30}$ revealed several severe limitations in terms of yields and reaction conditions, thus preventing an easy access to compounds $\mathbf{1}$ and $\mathbf{2}$ at gram scale required in the early stages of the preclinical development. To address this issue, we developed an optimized synthetic route for the preparation of both compounds (Scheme 1). The synthesis started by a lithiation step of pivaloylated $m$-anisidine 4 at $0{ }^{\circ} \mathrm{C}$ to afford the desired aldehyde $\mathbf{5}$ with an excellent and reproducible yield (96\%). The latter was subjected to a Friedländer reaction with methyl trans-3-methoxyacrylate furnishing quinoline ester 6 (70\% yield) which was subsequently refluxed in aqueous $\mathrm{HBr}$ to provide 5-hydroxy quinoline carboxylic acid 7 (99\% yield). After formation of 5-hydroxy quinoline methyl ester 8 in the presence of thionyl chloride in methanol (61\% yield), the carbamoyl moiety was smoothly introduced by reaction with dimethylcarbamoyl chloride in the presence of potassium carbonate in acetone at reflux to afford the carbamylated quinoline 9 in $72 \%$ yield. A trans-amidation reaction in water gave the expected amide $\mathbf{1 0}$ with a good yield (77\%). The quaternization step could be conducted at multigram scale in the presence of methyl iodide as the alkylating agent in acetonitrile at reflux to furnish quinolinium salt 2 in $94 \%$ yield. It is worth noting that quaternization is also made possible at a large scale by the use of dimethyl sulfate in anhydrous tetrahydrofuran (THF) at reflux with somewhat lower yield (84\%).

In the last step, dihydroquinoline $\mathbf{1}$ was obtained by regioselective reduction of $\mathbf{2}$ in the presence of sodium dithionite in a high purity $(97.8 \%$, HPLC-UV) which can be raised up to $99.2 \%$ by a simple purification process in water at $25{ }^{\circ} \mathrm{C}$. This synthetic route proved to be efficient and reproducible to produce prodrug 1 at milligram to multigram scale with an overall yield of $18 \%$ over nine steps. Most of the synthetic intermediates were isolated by simple filtration and washing or purified by recrystallization, which may be viewed as real assets for the chemical development. In addition, this

\section{Scheme $1^{a}$}

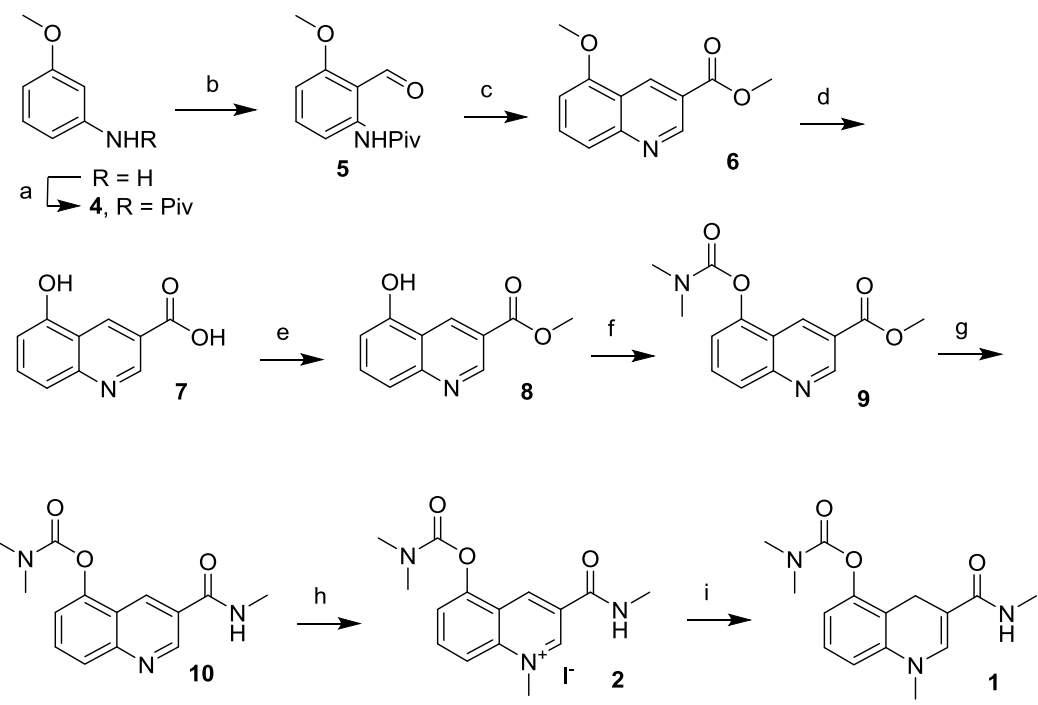

${ }^{a}$ Reagents and conditions: (a) PivCl, THF, NEt 3 , rt (96\%); (b) $n$-BuLi, THF, $0{ }^{\circ} \mathrm{C}$ then dimethylformamide (96\%); (c) methyl trans-3methoxyacrylate, $\mathrm{MeOH}, \mathrm{HCl} 37 \%$, reflux (70\%); (d) aq $\mathrm{HBr}$, reflux (99\%), (e) $\mathrm{SOCl}_{2}, \mathrm{MeOH}$, reflux (61\%); (f) dimethylcarbamoyl chloride, $\mathrm{K}_{2} \mathrm{CO}_{3}$, acetone, reflux (72\%); (g) $\mathrm{MeNH}_{2}, \mathrm{H}_{2} \mathrm{O}$, rt (77\%); (h) MeI, ACN, reflux (94\%); and (i) $\mathrm{Na}_{2} \mathrm{~S}_{2} \mathrm{O}_{4}, \mathrm{NaHCO}_{3}, \mathrm{CH}_{2} \mathrm{Cl}_{2} / \mathrm{H}_{2} \mathrm{O}, \mathrm{rt}(90 \%$ ). 
new route has three synthetic steps less than the original one ( 9 steps vs 12). Finally, both compounds 1 and 2 appear to be shelf-stable for at least 12 months provided that they are sheltered from the light and under an inert atmosphere $\left(\mathrm{N}_{2}\right)$.

UV Spectroscopy Study. In situ UV absorbance spectroscopy was first used to monitor the decarbamylation reaction of 2 by AChE. As expected, after synthesis of compound 3 (see Supporting Information), we could confirm that compounds 2 and 3 displayed different UV absorption maxima at 248 and $289 \mathrm{~nm}$, respectively, enabling us to follow the rate of disappearance of $\mathbf{2}$ and the rate of formation of $\mathbf{3}$ in the presence of electric eel AChE (Scheme 2). Owing to its

\section{Scheme 2}

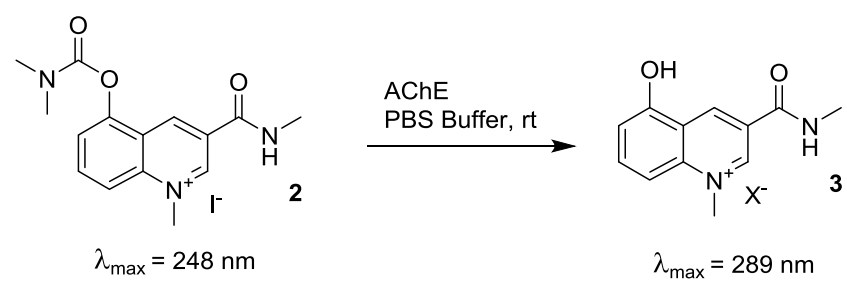

high homology with the active-site sequence of the human $\mathrm{AChE}^{32}$ and its commercial availability, eeAChE is commonly used for in vitro assays and was chosen for this study.

After addition of an excess of ligand 2 to a solution of eeAChE in phosphate-buffered saline (PBS) buffer ( $\mathrm{pH} 7.4)$ at $23{ }^{\circ} \mathrm{C}$, the absorption around $289 \mathrm{~nm}$ increased gradually for several hours which can be explained by the formation of expected product 3 . In the same time, the absorption at 248 $\mathrm{nm}$ decreased to the same extent during the same period (Figure 2). A control experiment in PBS buffer without eeAChE under the same reaction conditions was also made to ensure that in the absence of eeAChE, quinolinium 2 was not chemically converted into $3\left(t_{1 / 2}>24 \mathrm{~h}\right)$. For $24 \mathrm{~h}$, the concentration versus time data for the disappearance of 2 showed a total consumption of the substrate with a nearly quantitative transformation into compound 3. In these assay conditions, the initial velocity of the reaction was determined to be $0.256 \mu \mathrm{mol} \mathrm{h}{ }^{-1} \mathrm{~L}^{-1}$.
NMR Spectrometry Study. Both compounds 2 and 3 having no overlap of their ${ }^{1} \mathrm{H}$ NMR signals, we were also interested to confirm the previous results using NMR spectrometry by monitoring the decarbamylation of ligand $\mathbf{2}$ in the presence of AChE. The recombinant human AChE (rhAChE) was selected for this study because of its higher commercial purity compared to that of eeAChE. After full assignments of the proton signals of both compounds 2 and 3 with usual 1D and 2D NMR experiments in PBS buffer solution, decarbamylation reaction of ligand 2 was monitored by ${ }^{1} \mathrm{H}$ NMR experiments after addition of $8 \mu \mathrm{M}$ of hAChE to $100 \mu \mathrm{M}$ of ligand 2 (Figure $3 \mathrm{~b}-\mathrm{d}$ ). Under the above conditions, proton NMR spectra were recorded for every 2 h, indicating complete hydrolysis of ligand 2 by the hAChE within 10 days.

Analysis of the NMR proton spectra clearly shows the progressive disappearance of the ligand 2 signals and the occurrence of compound 3 signals. Indeed, the ${ }^{1} \mathrm{H}$ spectrum obtained after 5 days (Figure $3 \mathrm{c}$ ) shows that in addition to the characteristic signals of ligand 2 [i.e., methyl signal at $2.95 \mathrm{ppm}$ $(\mathrm{H} 7)$ and aromatic protons at $9.61 \mathrm{ppm}(\mathrm{H} 1), 9.44 \mathrm{ppm}(\mathrm{H} 2)$, $8.2 \mathrm{ppm}(\mathrm{H} 3$ and $\mathrm{H} 5)$, and $7.7 \mathrm{ppm}(\mathrm{H} 4)]$, new signals were observed at 2.92, 7.90, 6.8, 7.05, 9.32, and $9.13 \mathrm{ppm}$. These signals are characteristic of the $\mathrm{N}$-methylamide group and aromatic protons of compound 3. Not less noteworthy is the apparition of a singlet signal at $2.62 \mathrm{ppm}$ corresponding to the formation of dimethylamine that likely arises from hydrolysis of the carbamylated serine residue in the catalytic triad of AChE.

As predictable, the signal intensity of some specific protons of ligand 2 and compound 3 versus time curves was fitted with first order equations ( $R^{2}$ between 0.9489 and 0.9901 ), giving access to the absolute value of the rate constant $k$ of $3.5 \times 10^{-3}$ $\pm 0.3 \times 10^{-3} \mathrm{~h}^{-1}$ (Figure 4 ). It should be noted that the very high volatility of $N$-dimethylamine may explain the break observed after 6 days in the evolution of the $N$-dimethylamine signal intensity over time. All these findings highlight the decarbamylation of ligand 2 by hAChE leading to the formation of compounds 3, while the presence of $\mathrm{N}$ dimethylamine provides evidence of the reactivation of the active site of AChE.

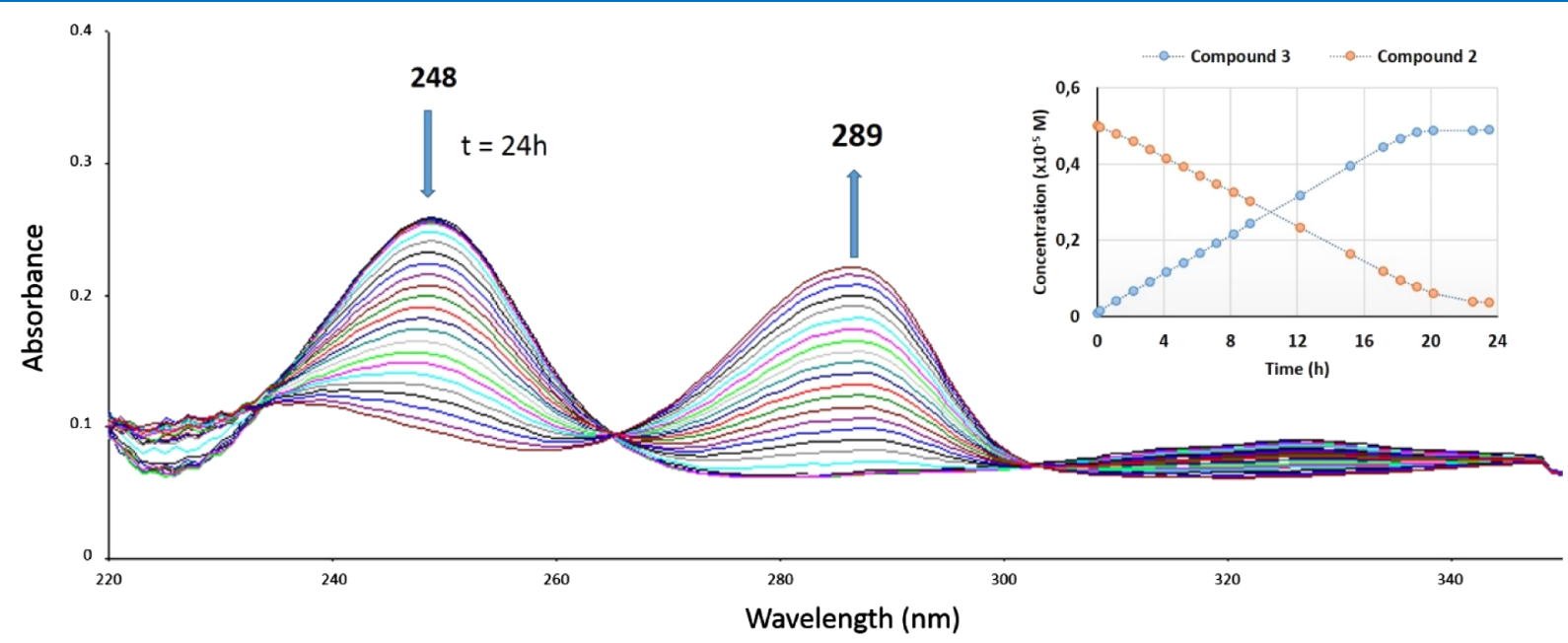

Figure 2. Evolution of the UV-visible spectral scans $(200-600 \mathrm{~nm})$ during enzymatic hydrolyze of compound 2 in the presence of eeAChE in PBS buffer ( $\mathrm{pH}$ 7.4) during $24 \mathrm{~h}$. In the inset: kinetic concentration traces for both compounds 2 and 3. 


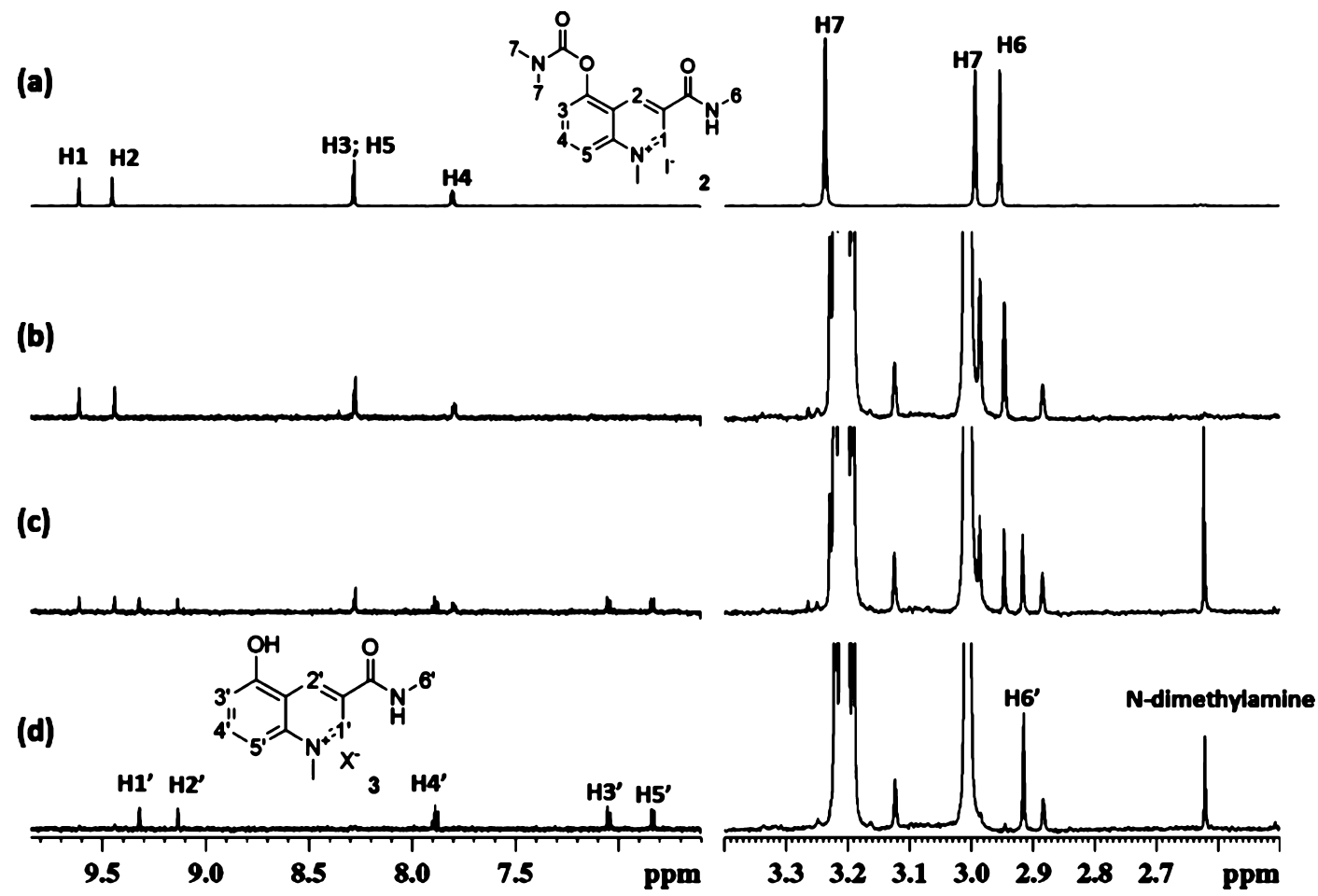

Figure 3. 1D proton NMR spectra $(600 \mathrm{MHz}, T=298 \mathrm{~K})$ in PBS $(10 \mathrm{mM}, \mathrm{pH}=7.4)$ : (a) ligand $2(6.67 \mathrm{mM})$; and ligand $2(100 \mu \mathrm{M})$ in the presence of $\mathrm{hAChE}(8 \mu \mathrm{M})$ performed at $(\mathrm{b}) t=0,(\mathrm{c}) t=5$ days, and $(\mathrm{d}) t=10$ days.
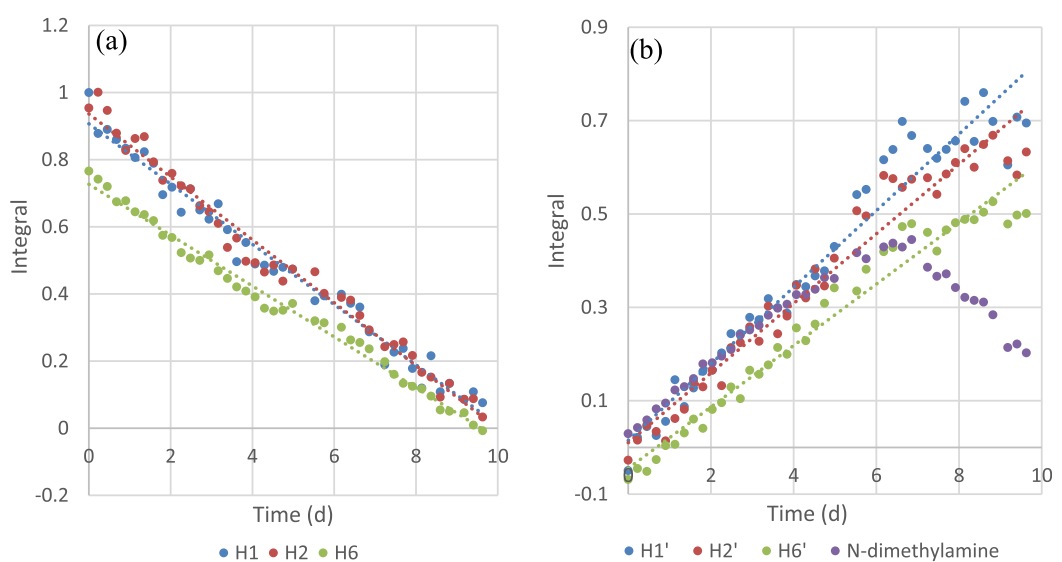

Figure 4. Kinetic monitoring of ligand $2(100 \mu \mathrm{M})$ decarbamylation by hAChE $(8 \mu \mathrm{M})$ in PBS $(10 \mathrm{mM}$, pH = 7.4): (a) compound 2 signal intensities over time of $\mathrm{H} 1, \mathrm{H} 2$, and H6. (b) Compound 3 signal intensities overtime of $\mathrm{H}^{\prime}, \mathrm{H} 2^{\prime}$, and $\mathrm{H}^{\prime}$ and $\mathrm{N}$-dimethylamine signal intensity.

Carbamylation of Ser 234 Residue Located at the "Esterasic Site" of hAChE Highlighted by Mass Spectrometry. To demonstrate the presumed pseudoirreversible inhibition mechanism of compound $\mathbf{2}$ involving the carbamylation of the active-site Ser 234 residue, we looked at detecting by mass spectrometry the modified peptides from the active-site region obtained after subsequent preincubation of enzyme with ligand $\mathbf{2}$ and digestion with proteolytic enzyme. Although this approach has been widely used for the detection of modified active site of $\mathrm{BuChE}$ enzyme by organophosphate pesticides or chemical warfare agents, ${ }^{33-35}$ rare examples were found in the literature for the detection of carbamate $\mathrm{BuChE}$ adducts by $\mathrm{LC} / \mathrm{MS} / \mathrm{MS}^{36}$ On the one hand, this can be probably explained by the higher spontaneous reactivation of carbamylated esterases and ${ }^{37}$ on the other hand by the very high lability of the carbamate group during the whole process of digestion and analysis, making the detection of such adducts extremely challenging. More importantly, only a few reports described the tryptic digestion for the organophosphatemodified AChE enzyme. ${ }^{32,37-40}$ More recently, ${ }^{41,42}$ the chymotrypsin was successfully used for the digestion of OPmodified recombinant mouse AChE. Nevertheless, chymotrypsin being less specific, there is a risk to generate lot of small hydrophobic peptides with near $\mathrm{m} / z$ values, making the analysis and interpretation difficult. To our knowledge, the detection of Ser234-modified peptides of rhAChE (accession number: P22303) by common carbamate ligands such as carbaryl, carbofuran, or rivastigmine (FDA-approved AChE inhibitors) has never been reported most likely for the reasons set out above. As a result, the detection of carbamate AChE adducts by LC/MS/MS remains a challenging task. rhAChE was chosen for this study and the conditions for enzyme 
Table 1. Detected Chymotryptic Digest Peptides Containing Ser 234 of Native rhAChE or after Modification with 2

\begin{tabular}{lccccc} 
& \multicolumn{3}{c}{${\text { untreated } \operatorname{rhAChE}[\mathrm{M}+2 \mathrm{H}]^{2+}}^{2}$} & & \\
\cline { 2 - 3 } peptide & 537.2377 & 537.2383 & 1.1 & treated rhAChE $[\mathrm{M}+2 \mathrm{H}]^{2+}$ detected $m / z$ & $\Delta$ mass $^{2+}(z=1)$ \\
GESAGAASVGMH & 542.2424 & 542.2449 & 4.6 & n.d. \\
FGESAGAASVGM & 545.2351 & 545.2359 & 1.4 & n.d. \\
GESAGAASVGmH & 610.7719 & 610.7766 & 7.6 & n.d. \\
FGESAGAASVGMH & 618.7693 & 618.7705 & 1.9 & n.d.
\end{tabular}

${ }^{a}$ Calculated using the PeptideMass tool on the ExPASy server. ${ }^{43,44}{ }^{b}$ See Supporting Information for Peaks software analysis. n.d.: not detected.
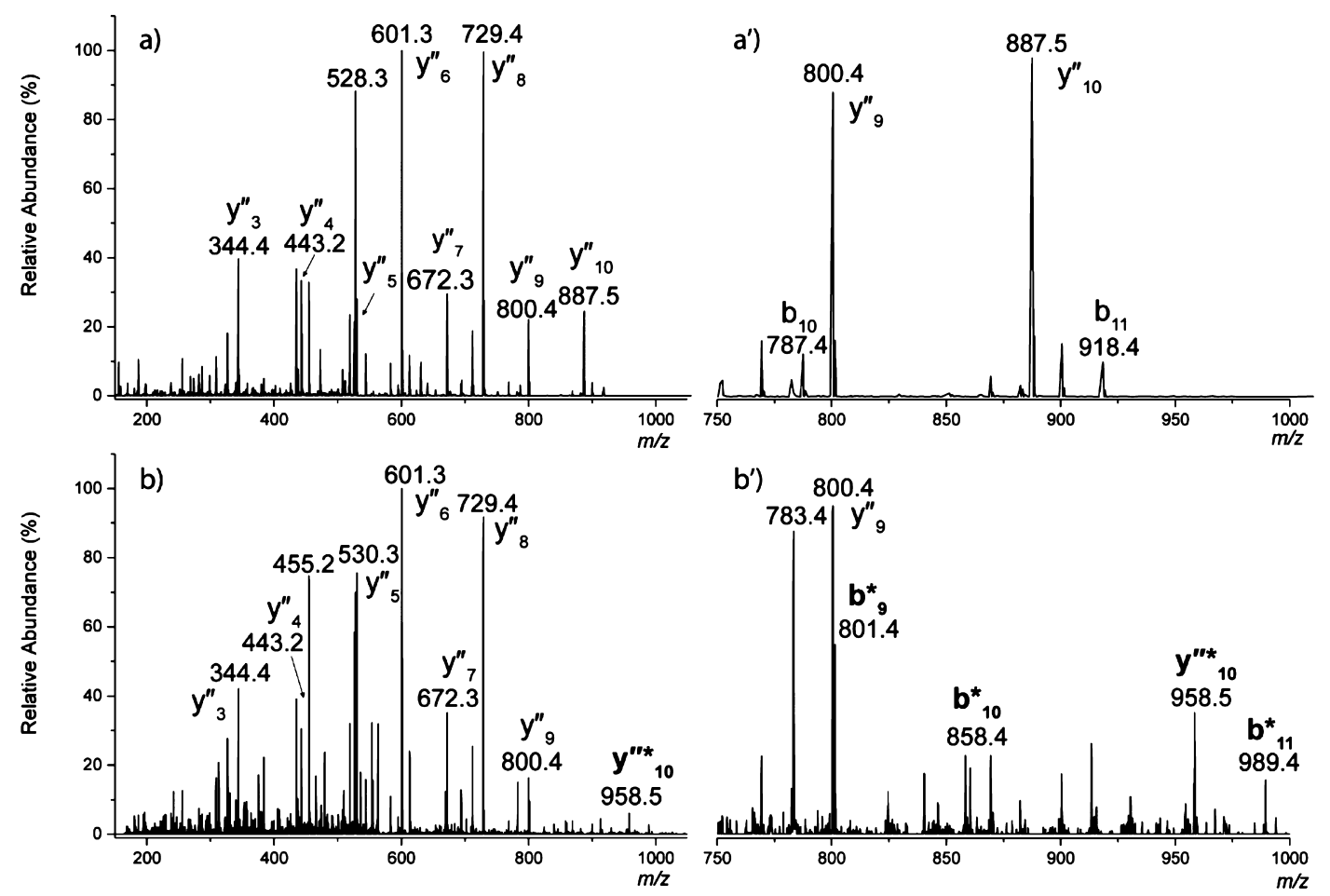

Figure 5. CID MS/MS spectra of (a) $m / z 537.2$ precursor ion from the untreated rhAChE sample with (a') inset of $m / z 750-1000$ (b) $m / z 572.7$ precursor ion from the treated rhAChE sample with $\left(\mathrm{b}^{\prime}\right)$ inset of $m / z 750-1000$ (asterisks correspond to derivatized ions).

digestion were inspired by the well-described work of Spaulding et al. $^{41}$ using chymotrypsin to generate digest of organophosphate-inactivated rMoAChE. Given that hAChE contains only three disulfide bridges, the classical steps of denaturation, disulfide bond reduction, and iodoacetamide alkylation were suppressed, thus avoiding numerous timeconsuming steps. Digestions of untreated and treated rhAChE were then conducted in the presence of $20 \%$ weight chymotrypsin at $25{ }^{\circ} \mathrm{C}$ for $17 \mathrm{~h}$. After concentration, the digests were directly analyzed and compared by electrospray ionization (ESI)-QTOF to detect any Ser234-modified peptides. Peak analysis of the obtained mass data revealed a protein coverage of $65 \%$ for untreated rhAChE (see Supporting Information). Further, doubly charged ions matching with small peptides containing the active-site sequence of rhAChE were detected (Table 1). Indeed, chymotryptic digestion of untreated rhAChE resulted in a formation of two dodecapeptides and three triskaidecapeptides. Among them, two peptides contain an oxidized methionine.

However, among these five possibilities to detect corresponding carbamylated peptides, only one doubly charged ion at $m / z 572.7$ was potentially observed with the expected delta of mass equivalent to the introduction of one dimethylcarbamyl group. To confirm these promising results, the collisioninduced dissociation (CID) tandem mass spectrometry experiment was performed on previously detected ions. For both doubly charged ions at $\mathrm{m} / z, 537.2$ and 572.7 , the amino acid sequences GESAGAASVGMH and carbamylated GESAGAASVGMH were clearly confirmed by the complete determination of $y$-ion series from $y_{3}$ to $y_{10}$ (Figure 5). Moreover, a mass shift of $71 \mathrm{u}$ for $\mathrm{y}_{10}, \mathrm{~b}_{9}, \mathrm{~b}_{10}$, and $\mathrm{b}_{11}$ ions was observed on the MS ${ }^{2}$ spectrum of the $m / z 572.7$ precursor ion, highlighting the modification at the active site of rhAChE treated by ligand 2 .

ADME, in Vitro Pharmacology and Preliminary in Vivo Toxicology. Compound 1 displayed favorable calculated physicochemical properties required for CNS drugs: a low molecular weight, few hydrogen bond donors, and low polar surface area (see Table 2). With a $\log D$ of 1.25 , compound 1 demonstrated high apparent permeability $\left(P_{\text {app }}\right.$ of $30.6 \times 10^{-6}$ $\mathrm{cm} / \mathrm{s}$ ) and an efflux ratio of 1.3 consistent with a passive diffusion mechanism. In aqueous solubility assays (shakeflask), it displayed moderate solubility in both PBS buffer ( $\mathrm{pH}$ 7.4) and fasted simulated intestinal fluid, respectively, 182 and $160 \mu \mathrm{M}$. The fraction of compound 1 bound to protein in 
Table 2. Experimental and Calculated Physicochemical Properties of Compound 1

\begin{tabular}{|c|c|}
\hline & prodrug 1 \\
\hline molecular weight $^{a}$ & 289.33 \\
\hline experimental $\log D^{b}$ & 1.25 \\
\hline aqueous solubility (PBS, $\mathrm{pH} 7.4 / \mathrm{SIF})^{b}$ & $182 / 160 \mu \mathrm{M}$ \\
\hline TPSA $\left(\AA^{2}\right)^{a}$ & 60 \\
\hline plasma stability $^{b}$ & $>60 \mathrm{~min}$ \\
\hline protein binding $^{b}$ & $67 \%(100 \%)^{c}$ \\
\hline intrinsic clearance, HLM & $\begin{aligned} t_{1 / 2} & >60 \mathrm{~min}, \\
\mathrm{Cl}_{\text {int }, \text { app }} & <115.5 \mu \mathrm{L} / \mathrm{min} / \mathrm{mg}\end{aligned}$ \\
\hline $\begin{array}{l}\text { intrinsic clearance, human cryopreserved } \\
\text { hepatocytes }\end{array}$ & $\begin{array}{l}t_{1 / 2}=75 \mathrm{~min}, \\
\mathrm{Cl}_{\text {int,app }}=13.3 \mu \mathrm{L} / \mathrm{min} / \mathrm{mg}\end{array}$ \\
\hline Caco 2 , $\mathrm{pH} 7.4 / 7.4\left(\mathrm{~cm} / \mathrm{s} \times 10^{-6}\right)^{b}$ & $\begin{array}{l}\mathrm{A} \rightarrow \mathrm{B}: 30.6 ; \mathrm{B} \rightarrow \mathrm{A} \text { 40.6; efflux } \\
\text { ratio: } 1.3\end{array}$ \\
\hline $\begin{array}{l}{ }^{a} \text { Calculated using Accelrys software. } \\
{ }^{c} \text { Recovery. }\end{array}$ & ${ }^{b}$ Assays performed by Cerep. \\
\hline
\end{tabular}

human plasma was determined by equilibrium dialysis and was moderate (67\%). In addition, compound 1 displayed moderate but acceptable in vitro metabolic stability in human liver microsomes $\left(t_{1 / 2}>60 \mathrm{~min}\right)$ and in human cryopreserved hepatocytes $\left(t_{1 / 2}=75 \mathrm{~min}\right)$.

To identify undesirable off-target activities, in vitro pharmacological profiling, involving the screening of prodrug 1 and its drug 2 against a broad range of targets among receptors, enzymes, ion channels, and transporters, was performed (see Supporting Information). In a panel of over 27 different receptors, 88 enzymes, 5 transporters, and 7 ion channel binding assays, compound $\mathbf{1}$ did not have appreciable activity for any target and compound $\mathbf{2}$ showed a very good selective and safety profile. Indeed, it did not have significant activity for any binding site other than acetylcholine esterase, which is particularly remarkable. In addition, to investigate whether compound 1 inhibits the major cytochrome P450 enzymes, in vitro studies have been performed including CYP1A2, CYP2B6, CYP2C8, CYP2C9, CYP2C19, CYP2D6, and CYP3A (see Supporting Information). No strong CYP inhibition activity $(\leq 38 \%)$ by compound 1 was observed at 10 $\mu \mathrm{M}$ in all different species, which suggests a low likelihood of drug-drug interactions. As recommended by FDA and EMA guidelines, in vitro inhibition studies of drug transporters have also been conducted for compound 1 and, at $10 \mu \mathrm{M}$, it does not inhibit any tested transporters $(\leq 21 \%$, see Supporting Information). The preliminary evaluation of risk of cardiotoxicity was also performed using automated patch-clamp hERG and Nav1.5 assays. In both cases, no strong channel inhibition by compound 1 was detected at three tested concentrations (respectively, for $\mathrm{K}^{+} / \mathrm{Na}^{+}$channels: $1 / 3 \%$ at $10^{-7} \mathrm{M}, 7 / 6 \%$ at $10^{-6} \mathrm{M}$, and $9 / 11 \%$ at $10^{-5} \mathrm{M}$ ).

Encouraging by the previous in vitro results, the in vivo preliminary toxicity of compound $\mathbf{1}$ was evaluated after 7 days of daily oral administration (gavage) to male winstar rats. A preliminary test to determine the maximum-tolerated dose
(MTD) was first performed starting from a dose of $50 \mathrm{mg} / \mathrm{kg}$ where clinical signs such as hunched posture or tremors were observed without occurring death. After decreasing the administrated dose to 25 then $15 \mathrm{mg} / \mathrm{kg}$, a dose of $20 \mathrm{mg} /$ $\mathrm{kg}$ did not induce any clinical signs and was chosen as the highest dose for the main test. A dose of $5 \mathrm{mg} / \mathrm{kg}$ was chosen as the lowest administrated dose.

At both selected dose levels, compound $\mathbf{1}$ did not induce mortality or any changes among hematology and blood biochemistry parameters, organ weights, or histopathological findings. The body weight gain and food consumption were also daily controlled. At the smallest dose, moderately higher body weight gain was observed over the treatment period. In addition, at $20 \mathrm{mg} / \mathrm{kg} /$ day, markedly higher body weight gain was observed over the treatment period, in spite of a lower food consumption during the first part of the treatment period (days 1-3). For both doses, clinical signs (hypoactivity, dyspnea, tremors, chromodacryorrhea, hunched posture, and/ or decreased grasping reflex) were only observed on the first day within $30 \mathrm{~min}$ to $1 \mathrm{~h}$ after administration and lasted $1-3 \mathrm{~h}$. No clinical signs were observed thereafter until the end of the treatment period for all animals.

During the first day of administration, prodrug $\mathbf{1}$ and its metabolite 2 were quantified by LCMSMS in plasma samples from 0.5 to $8 \mathrm{~h}$ at both dose levels (Table 3). The maximum plasma concentrations were rapidly reached to the median time of $0.5 \mathrm{~h}$ for compound 1 with no difference between dose levels. However, as expected, the plasma exposure of the prodrug 1 was well above the plasma exposure of the drug 2, approximately 20-40-fold.

We can also note that compound $\mathbf{1}$ and its metabolite $\mathbf{2}$ plasma exposures increased more than dose-proportionally between 5 and $20 \mathrm{mg} / \mathrm{kg} /$ day. None of these findings were considered to be adverse for the future development of the prodrug 1.

\section{CONCLUSIONS}

In this paper, it has been first shown that the preselected 1,4dihydroquinoline carbamate compound 1, prodrug of a submicromolar AChE inhibitor, was easily accessible at multigram scale with a good overall yield, i.e., $18 \%$ in nine steps. In the second part of our work, we have demonstrated using UV-vis and NMR protocols that in PBS buffer the ligand 2 was quantitatively converted into compound 3 by AChE. We then committed to prove that conversion of ligand 2 into compound 3 resulted from the carbamalytion of the active site of the enzyme. After identification by tandem mass spectrometry of five peptides containing Ser-234 from the chymotrypsin digest of rhAChE, we were pleased to identify a Ser-234-modified dodecapeptide using the same protocol after having preincubated AChE with the ligand 2 . To the best of our knowledge, this remarkable finding constitutes the first example in the literature of the identification of carbamylated active-site-modified peptides of AChE by mass spectrometry.

Table 3. Mean \pm SD (Median for $T_{\max }$ ) Prodrug 1 and Its Metabolite 2 Toxicokinetic Parameters

\begin{tabular}{|c|c|c|c|c|}
\hline compound & \multicolumn{2}{|c|}{$\mathrm{p} 1$} & \multicolumn{2}{|c|}{ compound 2} \\
\hline dose-level (mg/kg/day) & 5 & 20 & 5 & 20 \\
\hline$T_{\max }(\mathrm{h})$ & 0.5 & 0.5 & 0.5 & 0.5 \\
\hline$C_{\max }(\mathrm{ng} / \mathrm{mL})$ & $385 \pm 127$ & $4102 \pm 1546$ & $9.17 \pm 1.12$ & $110 \pm 38$ \\
\hline $\mathrm{AUC}_{0-t}(\mathrm{ng} \mathrm{h} / \mathrm{mL})$ & $444 \pm 117$ & $6605 \pm 460$ & $23.7 \pm 3.3$ & $199 \pm 40$ \\
\hline
\end{tabular}


In the final part, we mainly focused on the pharmacological selectivity of the AChE inhibitor 2 as well as the ADME and safety profiles of the prodrug 1 . In particular, we demonstrated that the ligand 2 exhibits an exceptional selectivity toward AChE among other screened enzymes or receptors. It is also true for prodrug $\mathbf{1}$ which revealed to be relatively inert against a broad range of targets. Finally, the results obtained for a 7 day preliminary in vivo toxicology on rats were reported. All together, the presented results in this paper pave the way to the preclinical development of this promising therapeutic candidate for the treatment of $\mathrm{AD}$ patients.

\section{MATERIALS AND METHODS}

All commercial reagents were used without further purification. The solvents were dried with appropriate desiccants and distilled prior to use or were obtained anhydrous from commercial suppliers. Recombinant hAChE was purchased as a lyophilized powder from Sigma-Aldrich (catalog number: C1682). AChE from electric eel was purchased as a lyophilized powder from Sigma-Aldrich (catalog number: C2888). Silica gel $(60,230-400$ mesh) was used for column chromatography. Reactions were monitored by thin-layer chromatography on silica gel-precoated aluminum plates. UV light at 254 $\mathrm{nm}$ or $\mathrm{KMnO}_{4}$ stains was used to visualize TLC plates. ${ }^{1} \mathrm{H}$ and ${ }^{13} \mathrm{C}$ NMR spectra were recorded using a spectrometer operating at 300 and $75 \mathrm{MHz}$, respectively. Abbreviations used for peak multiplicities are s: singlet, d: doublet, t: triplet, q: quadruplet, $\mathrm{dd}=$ doublet of doublet, $\mathrm{br}=$ broad, and $\mathrm{m}$ : multiplet. Coupling constants $J$ are in $\mathrm{Hz}$, and chemical shifts are given in ppm and calibrated with DMSO- $d_{6}, \mathrm{CD}_{3} \mathrm{OD}$, or $\mathrm{CDCl}_{3}$ (residual solvent signals). High-resolution mass spectrometry (HRMS) data were obtained on a Shimadzu Prominence UFLC system with a Thermo Fisher LTQ Orbitrap Discovery. The relative purity $\geq 95 \%$ of the products was confirmed by LC/UV $(220-420 \mathrm{~nm})$ on a Thermo spectra system P1000XR HPLC photodiode array detector system using the following conditions: column, Hypersil Gold C18 $100 \times 2.1 \mathrm{~mm} ; 3 \mu \mathrm{m}$; solvent A, $20 \mathrm{mM}$ ammonium acetate; solvent $\mathrm{B}, \mathrm{CH}_{3} \mathrm{CN}$; flow rate, $0.2 \mathrm{~mL} / \mathrm{min}$ at $23{ }^{\circ} \mathrm{C}$; and run time, $45 \mathrm{~min}$. Method A: gradient from 20 to $80 \%$ solvent B over $18 \mathrm{~min}$; method B: gradient from 8 to $50 \%$ solvent B over $18 \mathrm{~min}$; method C: gradient from 8 to $35 \%$ solvent B over $18 \mathrm{~min}$; and method D: gradient from 8 to $25 \%$ solvent B over $18 \mathrm{~min}$.

$\mathrm{N}$-(3-Methoxyphenyl)pivalamide (4). Under mechanical stirring, to a solution of $m$-anisidine $(38.09 \mathrm{~g}, 0.31 \mathrm{~mol})$ in dichloromethane $(300 \mathrm{~mL})$ was added triethylamine $(32.53 \mathrm{~g}$, $0.32 \mathrm{~mol})$ at room temperature followed by the slow addition of pivaloyl chloride $\left(39.56 \mathrm{~g}, 0.32 \mathrm{~mol}\right.$ ) at $0{ }^{\circ} \mathrm{C}$ (internal temperature). The reaction mixture was maintained at $0{ }^{\circ} \mathrm{C}$ until total disappearance of the starting material (approximatively $30 \mathrm{~min}$ ). To the reaction mixture was then added 3 $\mathrm{M} \mathrm{HCl}$ solution $(200 \mathrm{~mL})$ at $0{ }^{\circ} \mathrm{C}$, and after phase separation, the aqueous layer was extracted with dichloromethane $(3 \times$ $100 \mathrm{~mL}$ ), and the combined organic layer was washed successively with water $(300 \mathrm{~mL})$ and brine $(300 \mathrm{~mL})$, dried over $\mathrm{MgSO}_{4}$, filtered, and concentrated in vacuo. The obtained wet solid was dried in vacuo at $50{ }^{\circ} \mathrm{C}$ overnight to give the protected compound $4(63.20 \mathrm{~g}, 96 \%)$ as a white solid which was used for the next step without any purification. HPLC purity: 96.8 area \% (HPLC condition A, $254 \mathrm{~nm}$ ). Retention times: $16.1 \mathrm{~min} . \mathrm{mp} 126-127^{\circ} \mathrm{C} . R_{\mathrm{f}}=0.36$ (petroleum ether/ EtOAc $=7: 3) .{ }^{1} \mathrm{H}$ NMR $\left(300 \mathrm{MHz}, \mathrm{CDCl}_{3}\right): \delta 7.39(\mathrm{t}, J=2.1$
$\mathrm{Hz}, 1 \mathrm{H}), 7.34(\mathrm{~s}, 1 \mathrm{H}), 7.19(\mathrm{t}, J=8.1 \mathrm{~Hz}, 1 \mathrm{H}), 6.92-6.95(\mathrm{~m}$, $1 \mathrm{H}), 6.64(\mathrm{ddd}, J=8.1 \mathrm{~Hz}, J=2.7 \mathrm{~Hz}, J=0.6 \mathrm{~Hz}, 1 \mathrm{H}), 3.80$ (s, 3H), 1.31 (s, 9H) ppm. ${ }^{13} \mathrm{C} \mathrm{NMR}\left(75 \mathrm{MHz}, \mathrm{CDCl}_{3}\right): \delta$ 176.4, 160.3, 139.4, 129.6, 111.9, 110.4, 105.4, 55.4, 39.7, 27.7 ppm. HRMS (ESI+) mass: calcd for $[\mathrm{M}+\mathrm{H}]^{+} \mathrm{C}_{12} \mathrm{H}_{18} \mathrm{NO}_{2} \mathrm{~m} /$ $z$, 208.1338; found, 208.1338.

$\mathrm{N}$-(2-Formyl-3-methoxyphenyl)pivalamide (5). Under an inert atmosphere, to a solution of compound 4 (63.0 g, 0.30 $\mathrm{mol})$ in THF $(500 \mathrm{~mL})$ was added dropwise $n-\mathrm{BuLi}(301 \mathrm{~mL}$, $0.75 \mathrm{~mol}, 2.5 \mathrm{M}$ in hexane) at $-15^{\circ} \mathrm{C}$. During the addition, the internal temperature must be maintained below $0{ }^{\circ} \mathrm{C}$. This reaction mixture was stirred for $3 \mathrm{~h}$ at $0{ }^{\circ} \mathrm{C}$; then, DMF (49.4 $\mathrm{mL}, 0.64 \mathrm{~mol}$ ) was added dropwise at the same temperature. The reaction mixture was allowed to rise to room temperature and stirred for an additional $2 \mathrm{~h}$. The reaction was then quenched by addition of a saturated aqueous solution of $\mathrm{NH}_{4} \mathrm{Cl}(300 \mathrm{~mL})$ at $0{ }^{\circ} \mathrm{C}$. After phase separation, the aqueous layer was extracted with diethylether $(3 \times 300 \mathrm{~mL})$, and the combined organic layer was washed successively with water $(300 \mathrm{~mL})$ and brine $(300 \mathrm{~mL})$, dried over $\mathrm{MgSO}_{4}$, filtered, and concentrated in vacuo. The obtained wet solid was dried during $24 \mathrm{~h}$ in vacuo at $60{ }^{\circ} \mathrm{C}$ to give compound 5 (71.0 g, $96 \%)$ as a yellow solid which was used for the next step without any purification. HPLC purity: 96.4 area \% (HPLC condition A, $230 \mathrm{~nm}$ ). Retention times: $19.5 \mathrm{~min} . \mathrm{mp} 82^{\circ} \mathrm{C} . R_{\mathrm{f}}$ $=0.16$ (petroleum ether $/$ EtOAc $=9: 1) .{ }^{1} \mathrm{H} \mathrm{NMR}(300 \mathrm{MHz}$, $\left.\mathrm{CDCl}_{3}\right): \delta 11.90($ br s, $1 \mathrm{H}), 10.52(\mathrm{~s}, 1 \mathrm{H}), 8.36(\mathrm{~d}, J=8.7 \mathrm{~Hz}$, $1 \mathrm{H}), 7.51(\mathrm{t}, J=8.4 \mathrm{~Hz}, 1 \mathrm{H}), 6.62(\mathrm{~d}, J=8.4 \mathrm{~Hz}, 1 \mathrm{H}), 3.91(\mathrm{~s}$, $3 \mathrm{H}), 1.34$ (s, 9H) ppm. ${ }^{13} \mathrm{C} \mathrm{NMR}\left(75 \mathrm{MHz} \mathrm{CDCl}_{3}\right): \delta 193.4$, $176.7,163.2$, 142.8, 137.8, 112.0, 111.1, 104.8, 55.9, 40.5, 27.6 ppm. HRMS (ESI+) mass: calcd for $[\mathrm{M}+\mathrm{H}]^{+} \mathrm{C}_{13} \mathrm{H}_{18} \mathrm{NO}_{3} \mathrm{~m} /$ $z$, 236.1287; found, 236.1277 .

Methyl 5-Methoxyquinoline-3-carboxylate (6). To a solution of $5(37.0 \mathrm{~g}, 0.15 \mathrm{~mol})$ and methyl trans-3methoxyacrylate $(71.7 \mathrm{~mL}, 0.67 \mathrm{~mol})$ in $650 \mathrm{~mL}$ of methanol was slowly added $37 \%$ hydrochloric acid $(100 \mathrm{~mL})$ at room temperature. The resulting mixture was stirred at reflux for 17 h. The reaction mixture was then cooled to room temperature and methanol was removed by distillation. The resulting solution was extracted with diethylether $(4 \times 150 \mathrm{~mL})$ to remove soluble byproducts, and finally, the aqueous layer was added to an aqueous solution of $\mathrm{Na}_{2} \mathrm{CO}_{3}(117.0 \mathrm{~g}$ in $540 \mathrm{~mL})$ for $10 \mathrm{~min}$ at room temperature. The formed precipitate was then filtrated and rinsed with cold water $(3 \times 200 \mathrm{~mL})$. The wet solid was dried in vacuo at $50{ }^{\circ} \mathrm{C}$ for $24 \mathrm{~h}$ to give compound 6 as a pale brown solid (23.2 g, 70\%). HPLC purity: $99.0 \%$ area (HPLC condition A, $254 \mathrm{~nm}$ ). Retention times: $12.8 \mathrm{~min} . \mathrm{mp} 99-100{ }^{\circ} \mathrm{C} . R_{\mathrm{f}}=0.48\left(\mathrm{DCM} / \mathrm{Et}_{2} \mathrm{O}=\right.$ 1:1). ${ }^{1} \mathrm{H}$ NMR (300 MHz, $\left.\mathrm{CDCl}_{3}\right): \delta 9.42(\mathrm{~d}, J=2.1 \mathrm{~Hz}, 1 \mathrm{H})$, $9.24(\mathrm{~d}, J=2.1 \mathrm{~Hz}, 1 \mathrm{H}), 7.73-7.71(\mathrm{~m}, 2 \mathrm{H}), 6.91(\mathrm{dd}, J=5.1$ $\mathrm{Hz}, J=3.6 \mathrm{~Hz}, 1 \mathrm{H}), 74.04(\mathrm{~s}, 3 \mathrm{H}), 4.01$ (s, 3H) ppm. ${ }^{13} \mathrm{C}$ NMR (75 MHz, $\left.\mathrm{CDCl}_{3}\right): \delta 166.0,156.1,150.5,150.4,133.8$, 132.1, 121.9, 121.3, 119.4, 105.0, 55.9, 52.4 ppm. HRMS (ESI +) mass: calcd for $[\mathrm{M}+\mathrm{H}]^{+} \mathrm{C}_{12} \mathrm{H}_{12} \mathrm{NO}_{3} \mathrm{~m} / z, 218.0817$; found, 218.0811 .

5-Hydroxyquinoline-3-carboxylic Acid (7). Compound $6(52.00 \mathrm{~g}, 0.24 \mathrm{~mol})$ was placed in suspension in hydrobromic acid (47\% solution, $1.03 \mathrm{~kg}, 5.98 \mathrm{~mol}$ ), and the mixture was stirred at reflux for $94 \mathrm{~h}$. After cooling at $0{ }^{\circ} \mathrm{C}$, solid $\mathrm{NaOH}$ (300 g, $7.5 \mathrm{~mol}$ ) was carefully added until $\mathrm{pH}=8$. Then, the $\mathrm{pH}$ was finally adjusted to 5 by adding $37 \% \mathrm{HCl}$. The formed precipitate was then filtrated and rinsed with cold water $(600$ $\mathrm{mL}, 5{ }^{\circ} \mathrm{C}$ ). The wet solid was dried in vacuo at $80{ }^{\circ} \mathrm{C}$ to give 
compound 7 as a grey solid (45.0 g, 99\%). HPLC purity: 98.6\% area (HPLC condition A, $254 \mathrm{~nm}$ ). Retention times: 2.1 min. mp $261{ }^{\circ} \mathrm{C} .{ }^{1} \mathrm{H}$ NMR $\left(300 \mathrm{MHz}, \mathrm{DMSO}-d_{6}\right): \delta 13.38(\mathrm{br}$ s, $1 \mathrm{H}), 10.90(\mathrm{~s}, 1 \mathrm{H}), 9.24(\mathrm{~d}, J=2.1 \mathrm{~Hz}, 1 \mathrm{H}), 9.04(\mathrm{~d}, J=2.1$ $\mathrm{Hz}, 1 \mathrm{H}), 7.69(\mathrm{t}, J=8.1 \mathrm{~Hz}, 1 \mathrm{H}), 7.52(\mathrm{~d}, J=8.1 \mathrm{~Hz}, 1 \mathrm{H})$, $7.02(\mathrm{~d}, J=8.1 \mathrm{~Hz}, 1 \mathrm{H})$ ppm. ${ }^{13} \mathrm{C}$ NMR $(75 \mathrm{MHz}$, DMSO$\left.d_{6}\right): \delta 166.4,154.5,150.1,149.8,133.1,132.7,125.4,119.6$, 118.2, 109.5 ppm. HRMS (ESI+) mass: calcd for $[\mathrm{M}+\mathrm{H}]^{+}$ $\mathrm{C}_{10} \mathrm{H}_{8} \mathrm{NO}_{3} \mathrm{~m} / z$, 190.0504; found, 190.0501 .

Methyl 5-Hydroxyquinoline-3-carboxylate (8). To a suspension of compound $7(50.00 \mathrm{~g}, 0.26 \mathrm{~mol})$ in methanol $(600 \mathrm{~mL})$ was added dropwise the thionyl chloride $(96 \mathrm{~mL}$, $1.32 \mathrm{~mol}$ ) at $0{ }^{\circ} \mathrm{C}$, and the reaction mixture was refluxed for 17 h. After adding water $(500 \mathrm{~mL})$ at room temperature, solid $\mathrm{NaHCO}_{3}(98.0 \mathrm{~g})$ was slowly added until neutralization. The resulting mixture was extracted with EtOAc $(6 \times 100 \mathrm{~mL})$, and the combined organic layer was dried over $\mathrm{MgSO}_{4}$, and concentrated in vacuo. To the crude residue were added methanol $(1.5 \mathrm{~L})$ and charcoal black $(38.0 \mathrm{~g})$, and the mixture was heated to $50{ }^{\circ} \mathrm{C}$, filtrated, and concentrated in vacuo. The wet solid was dried in vacuo at $50{ }^{\circ} \mathrm{C}$ for $17 \mathrm{~h}$ to give compound 8 (33.1 g, 61\%) as a yellow solid. HPLC purity: 97.1 area \% (HPLC condition C). Retention times: $24.2 \mathrm{~min}$. mp $217{ }^{\circ} \mathrm{C}$; ${ }^{1} \mathrm{H}$ NMR $\left(300 \mathrm{MHz}, \mathrm{DMSO}-d_{6}\right): \delta 10.98$ (br s, $1 \mathrm{H}), 9.25(\mathrm{~d}, J=2.1 \mathrm{~Hz}, 1 \mathrm{H}), 9.06(\mathrm{~d}, J=2.1 \mathrm{~Hz}, 1 \mathrm{H}), 7.72(\mathrm{t}$, $J=8.1 \mathrm{~Hz}, 1 \mathrm{H}), 7.53(\mathrm{~d}, J=7.8 \mathrm{~Hz}, 1 \mathrm{H}), 7.03(\mathrm{~d}, J=7.8 \mathrm{~Hz}$, $1 \mathrm{H}), 3.94(\mathrm{~s}, 3 \mathrm{H}) \mathrm{ppm} .{ }^{13} \mathrm{C}$ NMR $\left(75 \mathrm{MHz}, \mathrm{DMSO}-d_{6}\right): \delta$ $165.1,154.4,150.0,149.1,132.9,132.8,120.7,118.8,117.9$, 109.4, $52.1 \mathrm{ppm}$. HRMS (ESI+) mass: calcd for $[\mathrm{M}+\mathrm{H}]^{+}$ $\mathrm{C}_{11} \mathrm{H}_{10} \mathrm{NO}_{3} \mathrm{~m} / z$, 204.0661; found, 204.0668.

Methyl 5-(Dimethylcarbamoyloxy)quinoline-3-carboxylate (9). To a suspension of hydroxyquinoline 8 (32.7 g, $0.16 \mathrm{~mol}$ ) and solid $\mathrm{K}_{2} \mathrm{CO}_{3}(33.3 \mathrm{~g}, 0.24 \mathrm{~mol})$ in anhydrous acetone $(600 \mathrm{~mL})$ was slowly added the dimethylcarbamoyl chloride $(17.8 \mathrm{~mL}, 0.19 \mathrm{~mol})$ at room temperature, and the mixture was stirred at reflux for $17 \mathrm{~h}$. After cooling to room temperature, the solid were filtered and the filtrate was concentrated to dryness. The crude residue was recrystallized twice in a mixture of dichloromethane and petroleum ether to give the desired carbamylated quinoline $9(32.0 \mathrm{~g}, 72 \%)$ as a white solid. HPLC purity: 97.0 area \% (HPLC condition B). Retention times: $19.8 \mathrm{~min} . \mathrm{mp} 114{ }^{\circ} \mathrm{C}$; ${ }^{1} \mathrm{H}$ NMR $(300 \mathrm{MHz}$, $\left.\mathrm{CDCl}_{3}\right): \delta 9.45(\mathrm{~d}, J=2.1 \mathrm{~Hz}, 1 \mathrm{H}), 8.96(\mathrm{~d}, J=2.1 \mathrm{~Hz}, 1 \mathrm{H})$, $8.04(\mathrm{~d}, J=8.4 \mathrm{~Hz}, 1 \mathrm{H}), 7.82(\mathrm{t}, J=8.1 \mathrm{~Hz}, 1 \mathrm{H}), 7.43(\mathrm{~d}, J=$ $8.4 \mathrm{~Hz}, 1 \mathrm{H}), 4.02(\mathrm{~s}, 3 \mathrm{H}), 3.29(\mathrm{~s}, 3 \mathrm{H}), 3.09(\mathrm{~s}, 3 \mathrm{H}) \mathrm{ppm} .{ }^{13} \mathrm{C}$ NMR (75 MHz, $\left.\mathrm{CDCl}_{3}\right): \delta 165.8,154.4,150.3,150.2,147.9$, 133.3, 131.6, 126.7, 123.1, 121.7, 119.7, 52.7, 37.1, 36.8 ppm. HRMS (ESI+) mass: calcd for $[\mathrm{M}+\mathrm{H}]^{+} \mathrm{C}_{14} \mathrm{H}_{15} \mathrm{~N}_{2} \mathrm{O}_{4} \mathrm{~m} / z$, 275.1032; found, 275.1021 .

3-(Methylcarbamoyl)quinolin-5-yl Dimethylcarbamate (10). To a suspension of methyl ester 9 (32.0 g, 0.16 $\mathrm{mol})$ in deionized water $(520 \mathrm{~mL})$ was slowly added a $40 \%$ aqueous solution of methylamine in water $(100 \mathrm{~mL})$ at room temperature. After complete conversion of starting material, the reaction mixture was neutralized by addition of $37 \%$ aqueous $\mathrm{HCl}$ until $\mathrm{pH}=7$. The resulting mixture was extracted with dichloromethane $(4 \times 300 \mathrm{~mL})$, and the combined organic layer was dried over $\mathrm{MgSO}_{4}$ and concentrated in vacuo to afford the amide $\mathbf{1 0}(31.9 \mathrm{~g}, 77 \%)$ as a pale yellow solid. HPLC purity: 100.0 area \% (HPLC condition C). Retention times: $18.7 \mathrm{~min} . \mathrm{mp} 182{ }^{\circ} \mathrm{C}$; ${ }^{1} \mathrm{H} \mathrm{NMR}\left(300 \mathrm{MHz}, \mathrm{CDCl}_{3}\right): \delta$ $9.16(\mathrm{~d}, J=2.1 \mathrm{~Hz}, 1 \mathrm{H}), 8.70(\mathrm{~d}, J=2.1 \mathrm{~Hz}, 1 \mathrm{H}), 7.99$ (d, $J=$ $8.4 \mathrm{~Hz}, 1 \mathrm{H}), 7.77(\mathrm{t}, J=7.8 \mathrm{~Hz}, 1 \mathrm{H}), 7.38(\mathrm{~d}, J=7.2 \mathrm{~Hz}, 1 \mathrm{H})$,
6.56 (br s, $1 \mathrm{H}), 3.25$ (s, 3H), $3.06(\mathrm{~s}, 3 \mathrm{H}), 3.04(\mathrm{~d}, J=4.8 \mathrm{~Hz}$, $3 \mathrm{H}) \mathrm{ppm} .{ }^{13} \mathrm{C} \mathrm{NMR}\left(75 \mathrm{MHz}, \mathrm{CDCl}_{3}\right): \delta 166.0,154.5,148.9$, $148.5,147.3,130.3,130.0,127.1,126.1,121.5,119.3,36.8$, 36.5, 26.7 ppm. HRMS (ESI+) mass: calcd for $[\mathrm{M}+\mathrm{H}]^{+}$ $\mathrm{C}_{14} \mathrm{H}_{16} \mathrm{~N}_{3} \mathrm{O}_{3} \mathrm{~m} / z$, 274.1192; found, 274.1191.

[1-Methyl-3-(methylcarbamoyl)quinolin-1-ium-5-yl] $\mathrm{N}, \mathrm{N}$-Dimethylcarbamate lodide (2). To a mechanically stirred solution of carbamylated quinoline 10 (24 g, 87.8 $\mathrm{mmol})$ in acetonitrile $(200 \mathrm{~mL})$ was added methyl iodide $(68$ $\mathrm{mL}, 1.1 \mathrm{~mol}$ ) at room temperature. The resulting mixture was then heated at reflux for $5 \mathrm{~h}$. After cooling at room temperature, diethylether $(500 \mathrm{~mL})$ was added and the mixture was stirred for $1 \mathrm{~h}$. The resulting yellow precipitate was filtered off, rinsed twice with diethylether, and dried under vacuum to afford the corresponding quinolinium salt 2 (34.2 g, 94\%) as a yellow solid. HPLC purity: 97.8 area \% (HPLC condition D). Retention times: $4.3 \mathrm{~min} . \mathrm{mp} 230{ }^{\circ} \mathrm{C} .{ }^{1} \mathrm{H} \mathrm{NMR}$ $\left(300 \mathrm{MHz}, \mathrm{CDCl}_{3}\right): \delta 11.0(\mathrm{~s}, 1 \mathrm{H}), 9.71(\mathrm{~s}, 1 \mathrm{H}), 9.11$ (br s, $1 \mathrm{H}), 8.25(\mathrm{t}, J=8.7 \mathrm{~Hz}, 1 \mathrm{H}), 8.05(\mathrm{~d}, J=9.2 \mathrm{~Hz}, 1 \mathrm{H}), 7.88(\mathrm{~d}$, $J=8.1 \mathrm{~Hz}, 1 \mathrm{H}), 4.82(\mathrm{~s}, 3 \mathrm{H}), 3.31(\mathrm{~s}, 3 \mathrm{H}), 3.10(\mathrm{~s}, 3 \mathrm{H}), 3.09$ $(\mathrm{d}, J=6.0 \mathrm{~Hz}, 3 \mathrm{H}) \mathrm{ppm} .{ }^{13} \mathrm{C} \mathrm{NMR}\left(75 \mathrm{MHz}, \mathrm{DMSO}-d_{6}\right): \delta$ $161.8,152.9,150.6,148.6,138.9,138.0,136.5,127.5,123.0$, 122.9, 116.2, 46.1, 36.8, 36.6, 26.4 ppm. HRMS (ESI+) mass: calcd for $[\mathrm{M}]^{+} \mathrm{C}_{15} \mathrm{H}_{18} \mathrm{~N}_{3} \mathrm{O}_{3} \mathrm{~m} / z, 288.1348$; found, 288.1355 .

1-Methyl-3-(methylcarbamoyl)-1,4-dihydroquinolin5-yl Dimethylcarbamate (1). Under argon and protected from the light, to a vigorously stirred solution of quinolinium salt $2(8.5 \mathrm{~g}, 20.5 \mathrm{mmol})$ in a degassed solvent mixture of dichloromethane $(350 \mathrm{~mL})$ and water $(350 \mathrm{~mL})$ were successively added sodium carbonate $(10.7 \mathrm{~g}, 126.9 \mathrm{mmol})$ and the solid sodium dithionite $(18.2 \mathrm{~g}, 104.4 \mathrm{mmol})$. The resultant biphasic solution was vigorously stirred at room temperature for $45 \mathrm{~min}$ then sodium carbonate $(5.3 \mathrm{~g}, 63.5$ $\mathrm{mmol}$ ) and solid sodium dithionite $(9.1 \mathrm{~g}, 57.2 \mathrm{mmol})$ were added again. This operation was repeated twice, and $45 \mathrm{~min}$ after the last addition, the starting material was totally consumed. Water $(100 \mathrm{~mL})$ was then added to the mixture and glacial acetic acid $(20 \mathrm{~mL})$ was slowly added to reach $\mathrm{pH}$ 6. After phase separation, the aqueous layer was extracted with dichloromethane $(4 \times 200 \mathrm{~mL})$, and the combined organic layer was washed twice with brine, dried $\left(\mathrm{MgSO}_{4}\right)$, and concentrated under vacuum to afford the 1,4-dihydroquinoline $1(5.3 \mathrm{~g}, 90 \%)$ as a pale pink solid. HPLC purity: 97.8 area \% (HPLC condition D). Retention times: $25.1 \mathrm{~min}$. mp $151^{\circ} \mathrm{C}$. ${ }^{1} \mathrm{H}$ NMR $\left(300 \mathrm{MHz}, \mathrm{CDCl}_{3}\right): \delta 11.0(\mathrm{~s}, 1 \mathrm{H}), 9.71(\mathrm{~s}, 1 \mathrm{H})$, $9.11($ br s, $1 \mathrm{H}), 8.25(\mathrm{t}, J=8.7 \mathrm{~Hz}, 1 \mathrm{H}), 8.05(\mathrm{~d}, J=9.2 \mathrm{~Hz}$, $1 \mathrm{H}), 7.88(\mathrm{~d}, J=8.1 \mathrm{~Hz}, 1 \mathrm{H}), 4.82(\mathrm{~s}, 3 \mathrm{H}), 3.31(\mathrm{~s}, 3 \mathrm{H}), 3.10$ $(\mathrm{s}, 3 \mathrm{H}), 3.09$ (d, $J=6.0 \mathrm{~Hz}, 3 \mathrm{H}) \mathrm{ppm} .{ }^{13} \mathrm{C} \mathrm{NMR}(75 \mathrm{MHz}$, $\left.\mathrm{CDCl}_{3}\right): \delta 168.2,154.4,150.1,140.5,139.3,127.5,115.9$, $115.4,109.4,99.1,39.1,36.8,36.6,26.4,21.5$ ppm. HRMS (ESI+) mass: calcd for $[\mathrm{M}+\mathrm{H}]^{+} \mathrm{C}_{15} \mathrm{H}_{20} \mathrm{~N}_{3} \mathrm{O}_{3} \mathrm{~m} / z$, 290.1505; found, 290.1512. Method of purification: compound 1 (388.0 $\mathrm{mg}, 1.34 \mathrm{mmol}$ ) was placed in suspension in degassed water under an argon atmosphere, and the mixture was stirred for 24 $\mathrm{h}$ at $25{ }^{\circ} \mathrm{C}$ in the dark. After centrifugation at $4000 \mathrm{rpm}$, the supernatant was removed and the solid was rinsed with degassed water. The last operation was repeated once and the resulting solid was dried under vacuum to afford compound 1 with high purity (356.1 mg, HPLC purity > 99\%).

UV Spectral Study. UV-vis spectral studies were performed on a Varian Cary 100 scan spectrometer. $10^{-2} \mathrm{M}$ stock solution of compound $\mathbf{2}$ and $\mathbf{3}$ was prepared in PBS buffer ( $\mathrm{pH}$ 7.4). Standard curves of six points fitted with Beer's 
law $(1-500 \mu \mathrm{M})$ were made for both compounds 2 and 3 . The enzyme stock solution was prepared by diluting commercial solid protein $(1.21 \mathrm{mg}, 1003$ units) with of PBS buffer (320 $\mu \mathrm{L}, \mathrm{pH} 7.4$ ). Blank solution was prepared by addition of $50 \mu \mathrm{L}$ of the abovementioned enzyme stock solution to $750 \mu \mathrm{L}$ of PBS buffer in a $0.8 \mathrm{~mL} \mathrm{UV-vis} \mathrm{cuvette.} \mathrm{The} \mathrm{scanning} \mathrm{kinetics}$ was performed after the addition of $400 \mu \mathrm{L}$ of a $10^{-5} \mathrm{M}$ solution of 2 (obtained by two successive dilution from $10^{-2} \mathrm{M}$ stock solution) to a UV-vis cuvette containing $50 \mu \mathrm{L}$ of enzyme stock solution and $350 \mu \mathrm{L}$ of PBS buffer ( $\mathrm{pH}$ 7.4). The spectra were recorded every minute for $10 \mathrm{~min}$ and then every hour until total consumption of ligand 2 . Concentrations for both compounds 2 and 3 were determined using the ratio difference spectrophotometric method (RD). ${ }^{45}$

NMR Kinetic Study. All measurements were performed at $298 \mathrm{~K}$ on a Bruker Avance III $600 \mathrm{MHz}$ spectrometer with a 5 $\mathrm{mm}$ triple resonance cryogenic probe. The assignments of all the signals were done with usual NMR experiments such as correlation spectroscopy, nuclear Overhauser effect spectroscopy, heteronuclear multiple quantum coherence, and heteronuclear multiple bond coherence. 1D ${ }^{1} \mathrm{H}$ NMR experiments were acquired with an excitation sculpting block for water suppression with NS $=192$ and $d_{1}=2 \mathrm{~s}$ for a total duration of $15 \mathrm{~min}$. The dried extracts of rhAChE were suspended in PBS buffer solution (PBS $10 \mathrm{mM}, \mathrm{pH}=7.4,9 / 1$ of $\mathrm{H}_{2} \mathrm{O} / \mathrm{D}_{2} \mathrm{O}$ ). Stock solution was initially prepared for the ligand then diluted in PBS with rhAChE with a ratio of $12.5 / 1$ $(100 \mu \mathrm{M} / 8 \mu \mathrm{M})$ in PBS. The spectra were recorded every $2 \mathrm{~h}$ until total consumption of ligand 2.

Liquid Chromatography Mass Spectrometry. The native recombinant h-AChE solution $(100 \mu \mathrm{L}, 500 \mu \mathrm{g} / \mathrm{mL}$ in PBS buffer $\mathrm{pH}=7.4$ ) and the modified L-h-AChE solution $[100 \mu \mathrm{L}$ of the previous native solution preliminarily incubated for $30 \mathrm{~min}$ at $37^{\circ} \mathrm{C}$ with an equal volume of the ligand 2 (100 $\mu \mathrm{M}$ in deionized water)] were digested overnight at $25^{\circ} \mathrm{C}$ with chymotrypsin (purchased from Promega) to a final protease/ protein ratio of $1: 10$. The protein digests were dried under vacuum and redissolved in $100 \mu \mathrm{L}$ of $\mathrm{ACN} /$ water (1:1). The samples were then desalted, purified, and concentrated through ZipTip (Millipore) prior to nanoLC-ESI-MS/MS analysis.

Tandem Mass Spectrometry. Purified peptide extracts were dried and dissolved in starting buffer for chromatographic elution, consisting of $3 \% \mathrm{CH}_{3} \mathrm{CN}$ and $0.1 \% \mathrm{HCOOH}$ in water. Peptides were enriched, separated, and analyzed using a 6520 Accurate-Mass Q-TOF LC/MS equipped with an HPLC-chip cube interface (Agilent Technologies, Massy, France). The values of collision energies were configured in the automatic mode. The best dissociations of the peptides of interest were obtained with values of $15-25 \mathrm{eV}$. The MS/MS data were extracted and converted into mzdata.xml format file using Mass Hunter software (version B.06.00, Agilent Technologies). The protein identification was then performed using "Peaks" software (version 7.5).

MS/MS experiments were also performed with an HCT Ultra ion-trap mass spectrometer equipped with an ESI source (Bruker Daltonics, Bremen, Germany). The optimized ESI parameters were capillary voltage set at $-3 \mathrm{kV}$, end plate voltage at $-2.5 \mathrm{kV}$, and skimmer voltage at $40 \mathrm{~V}$. Nitrogen was used as the drying $\left(9 \mathrm{~L} \mathrm{~min}^{-1}\right.$ flow rate, temperature of 300 ${ }^{\circ} \mathrm{C}$ ) and nebulizing (pressure of $40 \mathrm{psi}$ ) gas. Positive ions were detected using the standard enhanced mode with a scan rate of $8100 \mathrm{~m} / z$ units s${ }^{-1}$ and a mass resolution of $0.35 \mathrm{~m} / z$ units at half peak height (full width half-maximum) over a mass-to- charge range $(m / z) 50-1200$. Helium was the buffer gas. For MS/MS experiments, each precursor ion was selected with an isolation width of $2 \mathrm{~m} / z$ unit and was excited by a voltage of 1 $\mathrm{V}$. The low mass cut-off value (LCMO) was set at $28 \%$ of the precursor ion $m / z$ value.

7 days Repeated Dose Toxicity Study of 1 in Sprague-Dawley Rats. The solutions were formulated so that animals were injected with a maximal dosing volume of 5 $\mathrm{mL} / \mathrm{kg}$. The appropriate amount according to the dosage was mixed into a $0.5 \%$ methylcellulose. All of the animal procedures followed the guidelines for the care and handling of laboratory animals and were approved by the CIToxLAB France Ethical Committee. Sprague-Dawley [Crl CD (SD) IGS BR] male rats weighing approximately $200 \mathrm{~g}$ were obtained from Charles River Laboratories (Italy). The animals were kept in a temperature-controlled environment (airconditioning, $T=22 \pm 2{ }^{\circ} \mathrm{C}$ with a $12 \mathrm{~h}$ dark/light cycle and food and water were freely available. A preliminary MTD study was performed in order to select the dose levels. The animals were randomly divided into three groups of three animals. Each group of animals are administered different doses in formulation of test compounds $(0,5$, and $20 \mathrm{mg} / \mathrm{kg}$ ) during 7 days. The dose formulations were administered by gavage using a plastic syringe once a day at the same time during 7 days. Animals of the control group received the vehicle only. Blood samples were taken on the first day, and the plasma levels of the compounds $\mathbf{1}$ and $\mathbf{2}$ were determined by LC-MS/MS. The animals were observed at least once a day after administering compound $\mathbf{1}$ with following of any toxicity associated with cardiac, neurological, and behavioral such as tremors, convulsions, salivation, diarrhea, sleep, lacrimation, and feeding behavior in treated rats as a sign of acute toxicity. All animals were weighted on days 1, 4, and 7. After completion of the treatment period, all animals were deeply anesthetized by injection of sodium pentobarbital and sacrificed by exsanguination. Before euthanasia, blood samples were taken into lithium heparin tubes to record blood chemistry parameters, and a complete macroscopic postmortem and microscopic examinations were performed on alltreated animals. This will include examination of the external surfaces; all orifices; the cranial cavity; the external surfaces of the brain, the thoracic, abdominal, and pelvic cavities with their associated organs and tissues; and the neck with its associated organs and tissues.

\section{ASSOCIATED CONTENT}

Supporting Information

The Supporting Information is available free of charge on the ACS Publications website at DOI: 10.1021/acsomega.8b02121.

${ }^{1} \mathrm{H}$ and ${ }^{13} \mathrm{C}\left\{{ }^{1} \mathrm{H}\right\}$ NMR spectra, UV data, Mass spectrometry data, and in vitro $\mathrm{ADME}$ and pharmacology data (PDF)

\section{AUTHOR INFORMATION}

\section{Corresponding Authors}

*E-mail: vgembus@vfp-therapies.com (V.G.).

*E-mail: vincent.levacher@insa-rouen.fr (V.L.).

ORCID

Vincent Gembus: 0000-0001-6510-7608

Vincent Levacher: 0000-0002-6429-1965 


\section{Notes}

The authors declare no competing financial interest.

\section{ACKNOWLEDGMENTS}

This work was partly supported by INSA-Rouen, Rouen University, CNRS, Labex SynOrg (ANR-11-LABX-0029), and Région Haute-Normandie.

\section{REFERENCES}

(1) Schneider, L. S.; Mangialasche, F.; Andreasen, N.; Feldman, H.; Giacobini, E.; Jones, R.; Mantua, V.; Mecocci, P.; Pani, L.; Winblad, B.; Kivipelto, M. Clinical trials and late-stage drug development for Alzheimer's disease: an appraisal from 1984 to 2014. J. Intern. Med. 2014, 275, 251-283.

(2) Cummings, J. L.; Morstorf, T.; Zhong, K. Alzheimer's disease drug-development pipeline: few candidates, frequent failures. Alzheimer's Res. Ther. 2014, 6, 37.

(3) Cummings, J.; Lee, G.; Mortsdorf, T.; Ritter, A.; Zhong, K. Alzheimer's disease drug development pipeline: 2017. Alzheimer's Dementia 2017, 3, 367-384.

(4) Yaari, R.; Hake, A. Alzheimer's disease clinical trials: past failures and future opportunities. Clin. Invest. 2015, 5, 297-309.

(5) Scheltens, P.; Blennow, K.; Breteler, M. M. B.; de Strooper, B.; Frisoni, G. B.; Salloway, S.; Van der Flier, W. M. Alzheimer's disease. Lancet 2016, 388, 505-517.

(6) Hendrix, J. A.; Bateman, R. J.; Brashear, H. R.; Duggan, C.; Carrillo, M. C.; Bain, L. J.; DeMattos, R.; Katz, R. G.; Ostrowitzki, S.; Siemers, E.; Sperling, R.; Vitolo, O. V. Challenges, solutions, and recommendations for Alzheimer's disease combination therapy. Alzheimer's Dementia 2016, 12, 623-630.

(7) MacLeod, R.; Hillert, E.-K.; Cameron, R. T.; Baillie, G. S. The role and therapeutic targeting of $\alpha$-, $\beta$ - and $\gamma$-secretase in Alzheimer's disease. Future Sci. OA 2015, 1, FSO11.

(8) Panza, F.; Solfrizzi, V.; Frisardi, V.; Capurso, C.; D’Introno, A.; Colacicco, A. M.; Vendemiale, G.; Capurso, A.; Imbimbo, B. P. Disease-Modifying Approach to the Treatment of Alzheimers Disease. Drugs Aging 2009, 26, 537-555.

(9) Tomita, T. Secretase inhibitors and modulators for Alzheimer's disease treatment. Expert Rev. Neurother. 2009, 9, 661-679.

(10) Wolfe, M. S. $\gamma$-Secretase inhibitors and modulators for Alzheimer's disease. J. Neurochem. 2012, 120, 89-98.

(11) Panza, F.; Frisardi, V.; Solfrizzi, V.; Imbimbo, B. P.; Logroscino, G.; Santamato, A.; Greco, A.; Seripa, D.; Pilotto, A. Immunotherapy for Alzheimer's disease: from anti- $\beta$-amyloid to tau-based immunization strategies. Immunotherapy 2012, 4, 213-238.

(12) Lemere, C. A. Immunotherapy for Alzheimer's disease: hoops and hurdles. Mol. Neurodegener. 2013, 8, 36-42.

(13) Ballatore, C.; Brunden, K. R.; Huryn, D. M.; Trojanowski, J. Q.; Lee, V. M.-Y.; Smith, A. B., III Microtubule Stabilizing Agents as Potential Treatment for Alzheimer's Disease and Related Neurodegenerative Tauopathies. J. Med. Chem. 2012, 55, 8979-8996.

(14) Panza, F.; Solfrizzi, F.; Seripa, D.; Imbimbo, B. P.; Lozupone, M.; Santamato, A.; Zecca, C.; Barulli, M. R.; Bellomo, A.; Pilotto, A.; Daniele, A.; Greco, A.; Logroscino, G. Tau-Centric Targets and Drugs in Clinical Development for the Treatment of Alzheimer's Disease. BioMed Res. Int. 2016, 2016, 3245935.

(15) Wischik, C. M.; Harrington, C. R.; Storey, J. M. D. Tauaggregation inhibitor therapy for Alzheimer's disease. Biochem. Pharmacol. 2014, 88, 529-539.

(16) Bulic, B.; Pickhardt, M.; Mandelkow, E. Progress and Developments in Tau Aggregation Inhibitors for Alzheimer Disease. J. Med. Chem. 2013, 56, 4135-4155.

(17) Heneka, M. T.; Reyes-Irisarri, E.; Hüll, M.; Kummer, M. P. Impact and Therapeutic Potential of PPARs in Alzheimer's Disease. Curr. Neuropharmacol. 2011, 9, 643-650.

(18) Hoffmann, T.; Meyer, A.; Heiser, U.; Kurat, S.; Böhme, L.; Kleinschmidt, M.; Bühring, K.-U.; Hutter-Paier, B.; Farcher, M.; Demuth, H.-U.; Lues, I.; Schilling, S. Glutaminyl Cyclase Inhibitor
PQ912 Improves Cognition in Mouse Models of Alzheimer's DiseaseStudies on Relation to Effective Target Occupancy. J. Pharmacol. Exp. Ther. 2017, 362, 119-130.

(19) Wozniak, M. A.; Itzhaki, R. F. Antiviral agents in Alzheimer's disease: hope for the future? Ther. Adv. Neurol. Disord. 2010, 3, 141152.

(20) Whitcomb, D. J.; Molnár, E. Is riluzole a new drug for Alzheimer's disease? J. Neurochem. 2015, 135, 207-209.

(21) Alam, J. J. Selective Brain-Targeted Antagonism of p38 MAPK $\alpha$ Reduces Hippocampal IL-1 $\beta$ Levels and Improves Morris Water Maze Performance in Aged Rats. J. Alzheimer's Dis. 2015, 48, 219-227.

(22) Becker, R. E.; Greig, N. H.; Giacobini, E. Why Do So Many Drugs for Alzheimer's Disease Fail in Development? Time for New Methods and New Practices? J. Alzheimer's Dis. 2008, 15, 303-325.

(23) Vandenberghe, R.; Rinne, J. O.; Boada, M.; Katayama, S.; Scheltens, P.; Vellas, B.; Tuchman, M.; Gass, A.; Fiebach, J. B.; Hill, D.; Lobello, K.; Li, D.; McRae, T.; Lucas, P.; Evans, I.; Booth, K.; Luscan, G.; Wyman, B. T.; Hua, L.; Yang, L.; Brashear, R. S.; Black, R. $\mathrm{S}$. Bapineuzumab for mild to moderate Alzheimer's disease in two global, randomized, phase 3 trials. Alzheimer's Res. Ther. 2016, 8, 18.

(24) Doody, R. S.; Raman, R.; Farlow, M.; Iwatsubo, T.; Vellas, B.; Joffe, S.; Kieburtz, K.; He, F.; Sun, X.; Thomas, R. G.; Aisen, P. S.; Siemers, E.; Sethuraman, G.; Mohs, R. A Phase 3 Trial of Semagacestat for Treatment of Alzheimer's Disease. N. Engl. J. Med. 2013, 369, 341-350.

(25) Siemers, E. Drug development in AD: point of view from the industry. J. Prev. Alz. Dis. 2015, 2, 216-218.

(26) Henley, D. B.; Sundell, K. L.; Sethuraman, G.; Dowsett, S. A.; May, P. C. Safety profile of Semagacestat, a gamma-secretase inhibitor: Identity trial findings. Curr. Med. Res. Opin. 2014, 30, 2021-2032.

(27) Ali, T. B.; Schleret, T. R.; Reilly, B. M.; Chen, W. Y.; Abagyan, R. Adverse Effects of Cholinesterase Inhibitors in Dementia, According to the Pharmacovigilance Databases of the United-States and Canada. PLoS One 2015, 10, e0144337.

(28) Mimica, N.; Presečk, P. Side effects of approved antidementives. Psychiatr. Danubina 2009, 21, 108-113.

(29) Carøe, T. K.; Moe, C. Adverse events causing discontinuation of donepezil for Alzheimer's dementia. Ugeskr. Laeg. 2009, 171, 3690-3693

(30) Bohn, P.; Le Fur, N.; Hagues, G.; Costentin, J.; Torquet, N.; Papamicaël, C.; Marsais, F.; Levacher, V. Rational design of central selective acetylcholinesterase inhibitors by means of a "bio-oxidisable prodrug" strategy. Org. Biomol. Chem. 2009, 7, 2612-2618.

(31) Bohn, P.; Gourand, F.; Papamicaël, C.; Ibazizène, M.; Dhilly, M.; Gembus, V.; Alix, F.; Ţînţaş, M.-L.; Marsais, F.; Barré, L.; Levacher, V. Dihydroquinoline Carbamate Derivatives as "Biooxidizable" Prodrugs for Brain Delivery of Acetylcholinesterase Inhibitors: [11C] Radiosynthesis and Biological Evaluation. ACS Chem. Neurosci. 2015, 6, 737-744.

(32) Salih, E.; Chishti, S. B.; Vicedomine, P.; Cohen, S. G.; Chiara, D. C.; Cohen, J. B. Active-site peptides of acetylcholinesterase of Electrophorus electricus: labelling of His-440 by 1-bromo-[2-14C]pinacolone and Ser-200 by tritiated diisopropyl fluorophosphate. Biochim. Biophys. Acta 1994, 1208, 324-331.

(33) Noort, D.; Fidder, A.; van der Schans, M. J.; Hulst, A. G. Verification of exposure to organophosphates: generic mass spectrometric method for detection of human butyrylcholinesterase adducts. Anal. Chem. 2006, 78, 6640-6644.

(34) Sun, J.; Lynn, B. C. Development of a MALDI-TOF-MS method to identify and quantify butyrylcholinesterase inhibition resulting from exposure to organophosphate and carbamate pesticides. J. Am. Soc. Mass Spectrom. 2007, 18, 698-706.

(35) Marsillach, J.; Hsieh, E. J.; Richter, R. J.; MacCoss, M. J.; Furlong, C. E. Proteomic analysis of adducted butyrylcholinesterase for biomonitoring organophosphorus exposures. Chem.-Biol. Interact. 2013, 203, 85-90.

(36) Li, H.; Ricordel, I.; Tong, L.; Schopfer, L. M.; Baud, F.; Mégarbane, B.; Maury, E.; Masson, P.; Lockridge, O. Carbofuran 
poisoning detected by mass spectrometry of butyrylcholinesterase adduct in human serum. J. Appl. Toxicol. 2009, 29, 149-155.

(37) Reiner, E. Spontaneous reactivation of phosphorylated and carbamylated cholinesterases. Bull. W. H. O. 1971, 44, 109-112.

(38) Kropp, T. J.; Richardson, R. J. Aging of Mipafox-Inhibited Human Acetylcholinesterase Proceeds by Displacement of Both Isopropylamine Groups to Yield a Phosphate Adduct. Chem. Res. Toxicol. 2006, 19, 334-339.

(39) Elhanany, E.; Ordentlich, A.; Dgany, O.; Kaplan, D.; Segall, Y.; Barak, R.; Velan, B.; Shafferman, A. Resolving Pathways of Interaction of Covalent Inhibitors with the Active Site of Acetylcholinesterases: MALDI-TOF/MS Analysis of Various Nerve Agent Phosphyl Adducts. Chem. Res. Toxicol. 2001, 14, 912-918.

(40) Doorn, J. A.; Gage, D. A.; Schall, M.; Talley, T. T.; Thompson, C. M.; Richardson, R. J. Inhibition of Acetylcholinesterase by (1S,3S)Isomalathion Proceeds with Loss of Thiomethyl: Kinetic and Mass Spectral Evidence for an Unexpected Primary Leaving Group. Chem. Res. Toxicol. 2000, 13, 1313-1320.

(41) Spaulding, R.; George, K.; Thompson, C. Analysis and sequencing of the active-site peptide from native and organophosphate-inactivated acetylcholinesterase by electrospray ionization, quadrupole/time-of-flight (QTOF) mass spectrometryflight (QTOF) mass spectrometry. J. Chromatogr. B: Anal. Technol. Biomed. Life Sci. 2006, 830, 105-113.

(42) Yan, L.; Chen, J.; Xu, B.; Guo, L.; Xie, Y.; Tang, J.; Xie, J. A liquid chromatography tandem mass spectrometric method on in vitro nerve agents poisoning characterization and reactivator efficacy evaluation by determination of specific peptide adducts in acetylcholinesterase. J. Chromatogr. A 2016, 1450, 86-93.

(43) Wilkins, M. R.; Lindskog, I.; Gasteiger, E.; Bairoch, A.; Sanchez, J.-C.; Hochstrasser, D. F.; Appel, R. D. Detailed peptide characterization using PEPTIDEMASS - a World-Wide-Web-accessible tool. Electrophoresis 1997, 18, 403-408.

(44) Gasteiger, E.; Hoogland, C.; Gattiker, A.; Duvaud, S.; Wilkins, M. R.; Appel, R. D.; Bairoch, A. Protein Identification and Analysis Tools on the ExPASy Server. In The Proteomics Protocols Handbook; Walker, J. M., Ed.; Humana Press, 2005; pp 571-607.

(45) Lotfy, H. M.; Hegazy, M. A. M. Simultaneous determination of some cholesterol-lowering drugs in their binary mixture by novel spectrophotometric methods. Spectrochim. Acta, Part A 2013, 113, 107-114. 